\title{
Recent decrease trend of atmospheric mercury concentrations in East China: the influence of anthropogenic emissions
}

\author{
Yi Tang ${ }^{1,2}$, Shuxiao Wang ${ }^{1,2}$, Qingru Wu ${ }^{1,2}$, Kaiyun Liu ${ }^{1,2}$, Long $\mathrm{Wang}^{3}$, Shu $\mathbf{L i}^{1}$, Wei Gao ${ }^{4}$, Lei Zhang ${ }^{5}$, \\ Haotian Zheng ${ }^{1,2}$, Zhijian $\mathbf{L i}^{1}$, and Jiming Hao ${ }^{1,2}$ \\ ${ }^{1}$ State Key Joint Laboratory of Environmental Simulation and Pollution Control, School of Environment, \\ Tsinghua University, Beijing 100084, China \\ ${ }^{2}$ State Environmental Protection Key Laboratory of Sources and Control of Air Pollution Complex, \\ Beijing 100084, China \\ ${ }^{3}$ School of Environment and Energy, South China University of Technology, \\ Guangzhou 510006, China \\ ${ }^{4}$ Yangtze River Delta Center for Environmental Meteorology Prediction and Warning, \\ Shanghai 20030, China \\ ${ }^{5}$ State Key Laboratory of Pollution Control \& Resource Reuse, School of the Environment, \\ Nanjing University, Nanjing 210023, China
}

Correspondence: Shuxiao Wang (shxwang@tsinghua.edu.cn) and Qingru Wu (qrwu@tsinghua.edu.cn)

Received: 20 December 2017 - Discussion started: 1 February 2018

Revised: 9 May 2018 - Accepted: 18 May 2018 - Published: 14 June 2018

\begin{abstract}
Measurements of gaseous elemental mercury (GEM), other air pollutants, including $\mathrm{SO}_{2}, \mathrm{NO}_{x}, \mathrm{O}_{3}, \mathrm{PM}_{2.5}$, and $\mathrm{CO}$, and meteorological conditions were carried out at Chongming Island in East China from 1 March 2014 to 31 December 2016. During the sampling period, GEM concentrations significantly decreased from $2.68 \pm 1.07 \mathrm{ng} \mathrm{m}^{-3}$ in 2014 (March to December) to $1.60 \pm 0.56 \mathrm{ng} \mathrm{m}^{-3}$ in 2016 (March to December). Monthly mean GEM concentration showed a significant decrease, at a rate of $-0.60 \pm$ $0.08 \mathrm{ng} \mathrm{m}^{-3} \mathrm{yr}^{-1} \quad\left(R^{2}=0.64, p<0.01\right.$ significance level $)$. Combining the analysis of the potential source contribution function (PSCF), principle component analysis (PCA), and the emission inventory, we found that the Yangtze River Delta (YRD) region was the dominant source region of GEM in Chongming Island and the main source industries included coal-fired power plants, coal-fired industrial boilers, and cement clinker production. We further quantified the effect of emission change on the air $\mathrm{Hg}$ concentration variations at Chongming Island through a coupled method of trajectory clusters and air $\mathrm{Hg}$ concentrations. It was found that the reduction of domestic emissions was the main driver of GEM decline in Chongming Island, accounting for $70 \%$ of the total decline. The results indicated that air pollution control poli-
\end{abstract}

cies targeting $\mathrm{SO}_{2}, \mathrm{NO}_{x}$, and particulate matter reductions had significant co-benefits on GEM.

\section{Introduction}

Mercury $(\mathrm{Hg})$ is of crucial concern to public health and the global environment for its neurotoxicity, long-distance transport, and bioaccumulation. The atmosphere is an important channel for global $\mathrm{Hg}$ transport. Once atmospheric $\mathrm{Hg}$ deposits to the aquatic system, it can be transformed into methylmercury ( $\mathrm{MeHg}$ ), which bioaccumulates through the food web and affects the central nervous system of human beings (Mason et al., 1995). $\mathrm{Hg}$ is therefore on the priority list of several international agreements and conventions dealing with environmental protection, including the Minamata Convention on Mercury.

Atmospheric $\mathrm{Hg}$ exists in three operationally defined forms: gaseous elemental mercury (GEM), gaseous oxidized mercury (GOM), and particulate-bound mercury (PBM). And the sum of GEM and GOM is known as total gaseous mercury (TGM). In the atmosphere, $\mathrm{Hg}$ is mainly present as GEM, accounting for over $95 \%$ of the total at most obser- 
vation sites (Fu et al., 2015; Li et al., 2016; Zhang et al., 2013). GEM is stable, has a low solubility in the troposphere and a long residence time, and can be transported at regional and global scales (Lindberg et al., 2007). GEM can be oxidized through photochemical reaction to GOM, which can be converted to PBM upon adsorption/absorption on aerosol surfaces. GOM is more soluble than GEM, and PBM can be quickly scavenged by both dry and wet deposition. Therefore, the residence time of both GOM and PBM is shorter than that of GEM, generally several days to a few weeks for GOM and PBM and 0.5-2 year for GEM (Schroeder and Munthe, 1998).

The atmospheric $\mathrm{Hg}$ observation results are important evidence to help assess the effect of $\mathrm{Hg}$ emission control. During the past decades, significant decreases of GEM concentrations have been observed in Europe and North America (Cole et al., 2013; Weigelt et al., 2015). Air Hg concentrations in the Northern Hemisphere are reported to decline by 30-40\% between 1990 and 2010 (Y. Zhang et al., 2016). Such a decrease is consistent with the decrease in the anthropogenic $\mathrm{Hg}$ emissions inventory in Europe and North America (Streets et al., 2011). So far, most of the long-term observations on ground sites have been carried out in developed countries. For developing countries such as China, limited atmospheric $\mathrm{Hg}$ observations have been carried out ( $\mathrm{Fu}$ et al., 2008b; H. Zhang et al., 2016; Hong et al., 2016) and there is no official national observing network of atmospheric $\mathrm{Hg}$ in mainland China. Therefore, there are few continuous multi-year observation records of China's air $\mathrm{Hg}$ concentrations published (Fu et al., 2015).

China contributes to the largest $\mathrm{Hg}$ emissions in the world and will continue to be a significant $\mathrm{Hg}$ emitter for global $\mathrm{Hg}$ emissions in the future (UNEP, 2013; Wu et al., 2016; Chen et al., 2018; Pacyna et al., 2016). Large Hg emissions in China have led to average air $\mathrm{Hg}$ concentrations of $2.86 \pm 0.95 \mathrm{ng} \mathrm{m}^{-3}$ (in the range of $1.60-5.07 \mathrm{ng} \mathrm{m}^{-3}$ ) at remote sites in China (Fu et al., 2015). Such a Hg concentration level is approximately $1.3 \mathrm{ng} \mathrm{m}^{-3}$ higher than the background concentration of GEM in the Northern Hemisphere (Zhang et al., 2016; Sprovieri et al., 2017; Fu et al., 2015). In addition, large $\mathrm{Hg}$ emissions in China will also impact the air $\mathrm{Hg}$ concentrations in East Asia and even North America through long-range transport (Sung et al., 2018; Zhang et al., 2017). Meanwhile, China has a great potential for $\mathrm{Hg}$ emission reduction through the implementation of the Minamata Convention on Mercury (Chen et al., 2018). Therefore, longterm atmospheric $\mathrm{Hg}$ observations in China are critical to understand the $\mathrm{Hg}$ cycling at both regional and global scales. China's Hg emissions increased from $147 \mathrm{t} \mathrm{yr}^{-1}$ in 1978 to around $538 \mathrm{yr}^{-1}$ in 2010 due to dramatic economic development (L. Zhang et al., 2015; Wu et al., 2016; Hui et al., 2017). Atmospheric Hg monitoring that spanned from 2002 to 2010 in Guiyang, southwestern China, reflected the increase of $\mathrm{Hg}$ emissions in China (Fu et al., 2011). However, atmospheric $\mathrm{Hg}$ emissions in China are estimated to have decreased since

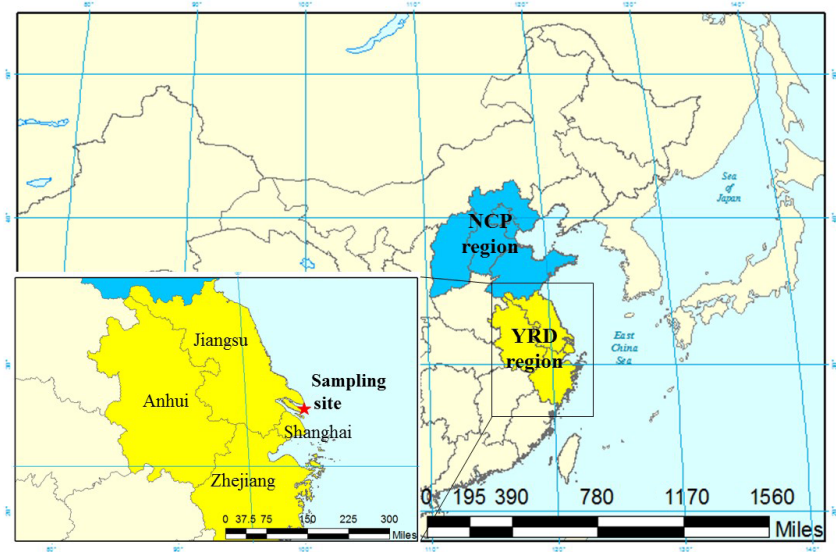

Figure 1. The location of the Chongming monitoring site in Shanghai, China.

2012 (Wu et al., 2016). This decreasing trend needs to be confirmed by atmospheric $\mathrm{Hg}$ observations.

In this study, we measured GEM, other air pollutants (e.g., $\mathrm{PM}_{2.5}$ and $\mathrm{NO}_{x}$ ), and meteorological parameters (e.g., temperature and wind speed) at the remote marine site of Chongming Island in East China during 2014-2016. We analyzed annual and seasonal variations of GEM and the potential impact factors. Combining the analysis of potential source contribution function (PSCF), principle component analysis (PCA), and the emission inventory, the potential source regions and source industries of atmospheric $\mathrm{Hg}$ pollution at the monitoring site were identified. In addition, a method which coupled trajectories and air $\mathrm{Hg}$ concentration was developed to assess the effect of $\mathrm{Hg}$ emission changes from different regions on air GEM concentration variation at the monitoring site.

\section{Materials and methods}

\subsection{Site descriptions}

The monitoring remote site $\left(31^{\circ} 32^{\prime} 13^{\prime \prime} \mathrm{N}, 121^{\circ} 58^{\prime} 04^{\prime \prime} \mathrm{E}\right.$; about $10 \mathrm{~m}$ a.s.l.) is located at the top of weather station in Dongtan Birds National Natural Reserve, Chongming Island, China (Fig. 1). As China's third largest island, Chongming Island is located to the east of the Yangtze River Delta region, with a typical subtropical monsoon climate. It is rainy and hot, with southern and southeastern winds in summer, and dry and cold, with northwestern wind in winter. The dominant surface types are farmland and wetland. There are no large anthropogenic emission sources in the island and no habitants within $5 \mathrm{~km}$ distance of the site. The downtown area of Shanghai is $50 \mathrm{~km}$ to the southwest of the site. 


\subsection{Sampling methods and analysis}

During the monitoring period, we used Tekran 2537X/1130/1135 instruments to monitor speciated $\mathrm{Hg}$ in the atmosphere, which has been widely used for air $\mathrm{Hg}$ observations worldwide. The sampling inlet was $1.5 \mathrm{~m}$ above the instrument platform. Continuous 5 min of GEM was measured by a Tekran $2537 \mathrm{X} \mathrm{Hg}$ vapor analyzer, with a detection limit of $0.1 \mathrm{ng} \mathrm{m}^{-3}$ at a sampling flow rate of $1.0 \mathrm{~L} \mathrm{~min}^{-1}$ during two campaigns: 1 March 2014 to 31 December 2015 and 26 March to 31 December 2016. From 5 July 2015 to 30 April 2016, the Tekran 1130/1135 speciation unit was damaged by the rainstorm; the Tekran $2537 \mathrm{X}$ was operated without speciation units but with a PTFE filter to protect the instrument from particles and sea salt. Therefore, the observed concentrations during July 2015April 2016 were TGM concentrations. However, the GOM concentrations at Chongming Island accounted for less than $1 \%$ of TGM $(\mathrm{TGM}=\mathrm{GOM}+\mathrm{GEM})$. Thus, the GEM concentrations were approximated to TGM concentrations from July 2015 to April 2016.

The $2537 \mathrm{X}$ analyzer was calibrated automatically every $25 \mathrm{~h}$ using the internal $\mathrm{Hg}$ permeation source inside the instrument, and the internal permeation source was calibrated every 12 months with manual injection of $\mathrm{Hg}$ by a syringe from an external $\mathrm{Hg}$ source (module 2505). Two zero and two span calibrations were performed for each calibration of gold trap A and B, respectively. The difference between gold trap A and gold trap B was limited to $\pm 10 \%$. The impactor plates and quartz filter were changed every 2 weeks. The soda lime was changed once a month. The denuders were re-coated once every 2 weeks following the procedure developed by Landis et al. (2002).

In our research, random uncertainties of individual measurement had been averaged out and the systematic uncertainties need to be considered. The overall practically achievable systematic uncertainty would be $10 \%$, considering that the instrument did not perform at an ideal level (Slemr et al., 2015; Steffen et al., 2012). For example, slow deactivation of the traps, contamination of the switching valves, and leaks would increase the uncertainty but were difficult to quantify (Slemr et al., 2015; Steffen et al., 2012). Because of the consistency of instrument and the quality assurance/quality control have been paid special attention to during the sampling campaign, the systematic differences of instrument did not affect the huge variation between 2014 and 2016.

During the sampling campaigns, $\mathrm{PM}_{2.5}, \mathrm{O}_{3}, \mathrm{NO}_{x}, \mathrm{CO}$, and $\mathrm{SO}_{2}$ were also monitored by Thermo Scientific TEOM 1405D, Model 49i $\mathrm{O}_{3}$ Analyzer, Model 48i CO Analyzer, Model 42i-TL $\mathrm{NO}_{x}$ Analyzer, and Model $43 \mathrm{i} \mathrm{SO}_{2}$ Analyzer, respectively. The detection limits of $\mathrm{O}_{3}, \mathrm{SO}_{2}, \mathrm{NO}_{x}, \mathrm{CO}$, and $\mathrm{PM}_{2.5}$ are $1.0,0.5,0.4,0.04$, and $0.1 \mu \mathrm{g} \mathrm{m}^{-3}$, respectively. The meteorological parameters including air temperature, wind speed, and wind direction were measured by a Vantage Pro2 weather station (Davis Instruments). The in- struments were tested and calibrated periodically. All data were averaged hourly in this study.

\subsection{Sources apportionment of atmospheric $\mathrm{Hg}$ pollution}

\subsubsection{PSCF model}

To identify the source areas for pollutants with a relatively long lifetime such as GEM (Xu and Akhtar, 2010), the PSCF values for mean GEM concentrations in grid cells in a study domain were calculated by counting the trajectory segment endpoints that terminate within each cell. The number of endpoints that fall in the $i j$ th cell are designated $n_{i j}$. The number of endpoints for which GEM concentrations correspond to arrival times higher than a specific criterion at the monitoring site for the same cell are defined by $m_{i j}$. The criterion in this study is set as the average $\mathrm{Hg}$ concentration during our study period. The PSCF value for the $i j$ th cell is then defined as

$\operatorname{PSCF}_{i j}=\frac{m_{i j}}{n_{i j}} W_{i j}$,

where $W_{i j}$ is an empirical weight to reduce the effects of grid cells with small $n_{i j}$ values. In this study, $W_{i j}$ is defined as in the following formula, in which Avg is the mean $n_{i j}$ of all grid cells with $n_{i j}$ greater than zero:

$W_{i j}=\left\{\begin{array}{lr}1.0 & n_{i j}>2 \cdot \text { Avg } \\ 0.7 & \text { Avg }<n_{i j} \leq 2 \cdot \text { Avg } \\ 0.42 & 0.5 \cdot \mathrm{Avg}<n_{i j} \leq \text { Avg } \\ 0.17 & n_{i j} \leq 0.5 \cdot \text { Avg }\end{array}\right.$.

The PSCF value indicates the probability of a grid cell through which polluted events occur. More method details can be found in the study of Polissar et al. (1999). In this study, the domain that covered the potential contribution source region $\left(105-135^{\circ} \mathrm{E}, 15-45^{\circ} \mathrm{N}\right)$ was divided into 22500 grid cells with $0.2^{\circ} \times 0.2^{\circ}$ resolution. The $72 \mathrm{~h}$ back trajectories were generated hourly from 1 March 2014 to 31 December 2015 and from 26 March to 31 December 2016 by TrajStat, software which includes HYSPLIT for trajectory calculation with trajectory statistics modules (Wang et al., 2009). The PSCF map was plotted using ArcGIS version 10.1 .

\subsubsection{Principal component analysis (PCA)}

Principal component analysis between $\mathrm{Hg}$ and other pollutant concentrations was used to identify potential sources. Strong positive loading (loading $>0.40$ ) with $\mathrm{SO}_{2}$ and $\mathrm{PM}_{2.5}$ typically indicates the impact of coal combustion, and strong positive loading with GEM and CO has often been used as an indicator for regional transport because both pollutants have similar source and stable chemical properties (Lin et al., 2006; Pirrone et al., 1996). In this study, PCA was applied to infer the possible influencing factors of GEM in 
2014 and 2016. Prior to analysis, each variable was normalized by dividing its mean, and pollutant concentrations $\left(\mathrm{SO}_{2}\right.$, $\mathrm{CO}, \mathrm{NO}_{x}, \mathrm{PM}_{2.5}$ ) were averaged to $1 \mathrm{~h}$ sampling intervals to match the hourly $\mathrm{Hg}$ monitoring during the sampling period. The results in 2016 had no CO data due to the instrument being broken. Statistics analyses were carried out using SPSS 19.0 software.

\subsection{Quantification method of source contribution}

To further quantitatively assess the effect of change in emissions from different regions on air concentration variation at a certain monitoring site, a quantitative estimation method which coupled trajectories with air $\mathrm{Hg}$ concentrations was developed. We firstly identified the trajectories using the National Oceanic and Atmospheric Administration (NOAA) Hybrid Single-Particle Lagrangian Integrated Trajectory (HYSPLIT) model. The gridded meteorological data at a horizontal resolution of $1^{\circ} \times 1^{\circ}$ were obtained from the Global Data Assimilation System (GDAS) (Draxler and Hess, 1998). The starting height was set to be $500 \mathrm{~m}$ above ground level to represent the center height of the boundary layer, where pollutants are usually well mixed. Secondly, each trajectory was assigned a GEM concentration by matching the arriving time at the Chongming site. Third, the backward trajectories which were coupled with $\mathrm{Hg}$ concentrations were clustered into groups according to transport patterns using NOAA HYSPLIT 4.7. Thus, the grouped clusters were applied to identify the $\mathrm{Hg}$ source regions. The $\mathrm{Hg}$ average concentration of the cluster $j$ was calculated as shown in Eq. (3), and the trajectory-weighted concentration in the cluster $j$ was calculated as shown in Eq. (4). Finally, the contribution of reduction at a certain region to $\mathrm{Hg}$ concentration at the monitoring sites in a certain period can be calculated as shown in Eq. (5).

$$
C_{j, t}=\frac{\sum_{i=1}^{n} C_{i, j, t}}{\sum_{i=1}^{n} N_{i, j, t}}
$$

$\mathrm{TWC}_{j, t}=\mathrm{AR} \times C_{j, t}$,

where $N$ refers to a certain trajectory, $j$ refers to a certain cluster, $t$ is the studied period, $n$ is the number of trajectory, and $m$ is the number of the cluster. $C$ is the GEM concentration, in $\mathrm{ng} \mathrm{m}^{-3}$. TWC refers to the trajectory-weighted concentration, in $\mathrm{n} \mathrm{m}^{-3}$. In order to reduce the influence of trajectory changes in different regions between calculated years, the average ratio (AR) was used here for calculating TWC.

$$
\mathrm{CR}_{j}=\frac{\mathrm{TWC}_{j, t_{2}}-\mathrm{TWC}_{j, t_{1}}}{\sum_{j=1}^{m} \mathrm{TWC}_{j, t_{2}}-\sum_{j=1}^{m} \mathrm{TWC}_{j, t_{1}}},
$$

where CR refers to the contribution of GEM reduction, and $t_{1}$ and $t_{2}$ refer to the two periods that are compared in this study, namely the years 2014 and 2016, respectively.

This approach is a simple method to quantify the influence of anthropogenic emissions on GEM concentration variation. It should be noted that uncertainties always exist in calculating trajectories, causing uncertainties in all trajectory-based approaches. Trajectory errors vary considerably in different situation. Draxler (1996) suggested uncertainties might be $10 \%$ of the travel distance. In addition, meteorological conditions were pretty similar in 2014 and 2016 so as to reduce the interference from meteorology (Table S2 in the Supplement).

\subsection{Regional atmospheric Hg emissions}

Regional anthropogenic GEM emissions by month were calculated using both the technology-based emission factor method and transformed normal distribution function method. A detailed introduction of these two methods and the speciation profile of the emitted $\mathrm{Hg}$ for each sector were described in our previous study (Wu et al., 2016). Conventional air pollutant $\left(\mathrm{SO}_{2}, \mathrm{PM}_{2.5}\right.$, and $\left.\mathrm{NO}_{x}\right)$ emissions were calculated following the study of Zhao et al. (2013). The source regions included in the emission inventory consisted of Shanghai, Jiangsu, Zhejiang, and Anhui provinces, according to the PSCF results (See Sect. 3.3). The studied emission sectors included coal-fired power plants, coal-fired industrial boilers, residential coal-combustion, cement clinker production, iron and steel production, mobile oil combustion, and other small emission sectors (e.g., zinc smelting, lead smelting, municipal solid incineration, copper smelting, aluminum production, gold production, other coal combustion, stationary oil combustion, and cremation). The monthly $\mathrm{Hg}$ emissions were mainly distributed according to fuel combustion or product production by month (Table S1). For small emission sectors, the annual emissions were equally distributed into monthly emissions.

The GEM emissions from natural sources $E_{\mathrm{N}}$ were calculated as follows:

$E_{\mathrm{N}}=\sum_{i} F_{i} \times A_{i} \times t$

where $F_{i}$ is a bidirectional $\mathrm{Hg}$ flux of canopy $i$, $\mathrm{ng} \mathrm{km}{ }^{-2} \mathrm{yr}^{-1} ; A$ is the studied area, $\mathrm{km}^{-2} ; t$ is the studied year, yr. The bidirectional $\mathrm{Hg}$ flux was obtained from the study of Wang et al. (2016) directly. It should be pointed out that the natural emission was a concept of net emission in this paper, which reflected a net effect of two competing processes (Zhang et al., 2009): total $\mathrm{Hg}$ natural emissions and total $\mathrm{Hg}$ deposition. The total natural emissions included primary natural release and re-emission of legacy $\mathrm{Hg}$ stored in the terrestrial and water surface (Wang et al., 2016). When the value is positive, it means the net effect is $\mathrm{Hg}$ emissions to air. Otherwise, $\mathrm{Hg}$ is deposited. 

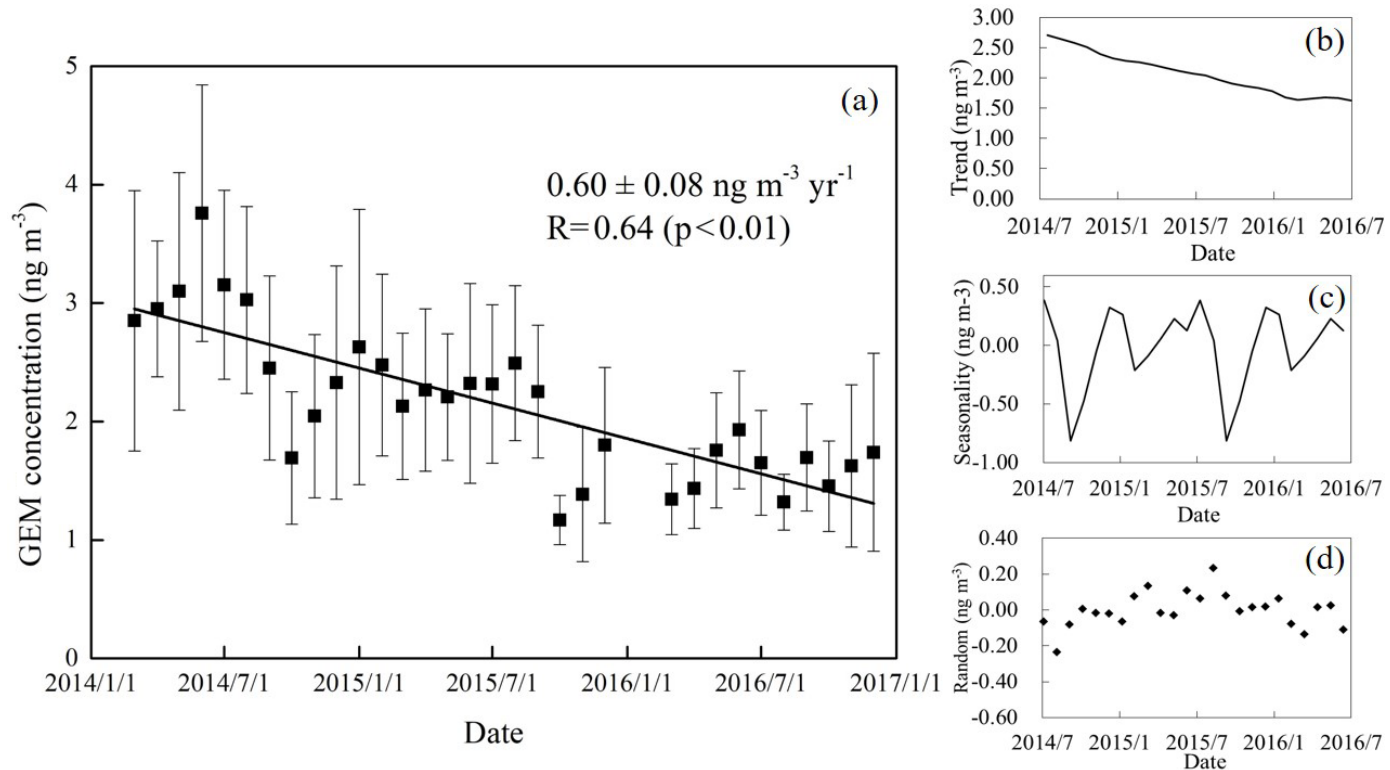

Figure 2. Monthly average GEM concentrations during the studied period: (a) observed monthly GEM concentrations, (b) GEM trend after decomposition, (c) GEM seasonality after decomposition, and (d) GEM random concentration after decomposition. Note that the observed concentrations during July 2015-April 2016 were TGM concentrations due to the problems of Tekran 1130/1135. However, the GOM concentrations at Chongming Island accounted for less than $1 \%$ of TGM. Thus, the GEM concentrations were approximated to TGM concentrations during July 2015-April 2016.

\section{Results and discussions}

\subsection{Decreasing trends of atmospheric Hg during 2014-2016}

The average concentrations of GEM in 2014 (March to December), 2015, and 2016 (March to December) were $2.68 \pm 1.07,2.14 \pm 0.82$, and $1.60 \pm 0.56 \mathrm{ng} \mathrm{m}^{-3}$, respectively. The GEM concentrations in 2014 were higher ( $t$ test, $p<0.01)$ than the Northern Hemisphere background concentrations (about $1.5 \mathrm{ng} \mathrm{m}^{-3}$ ) (Sprovieri et al., 2010) and those measured in other remote and rural locations in China $(\mathrm{H}$. Zhang et al., 2015; Fu et al., 2008a, 2009). However, in 2016, the GEM concentrations were similar to the background concentrations in the Northern Hemisphere. During this period, monthly GEM concentrations showed a significant decrease, at a rate of $-0.60 \pm 0.08 \mathrm{ng} \mathrm{m}^{-3} \mathrm{yr}^{-1}\left(R^{2}=0.64\right.$, $p<0.01$ significance level, $n=32$ ) (Fig. 2a). The amount of valid data for each mouth was shown in Table S3. In addition, the trend decomposition of the GEM concentration signal $($ signal $=$ trend + seasonal + random $)$ from March 2014 to December 2016 is shown in Fig. 2 (https://anomaly. io/seasonal-trend-decomposition-in-r/, last access: 26 May 2018). By using this method, we also observed a pronounced trend (Fig. 2b), and the random concentration was limited in the range of $-0.24-0.24 \mathrm{ng} \mathrm{m}^{-3}$ (Fig. 2d).

One potential worry was that the calculated trend was sensitive to seasonal variation and the missing data in January and February 2016 might impact the downward trend. To

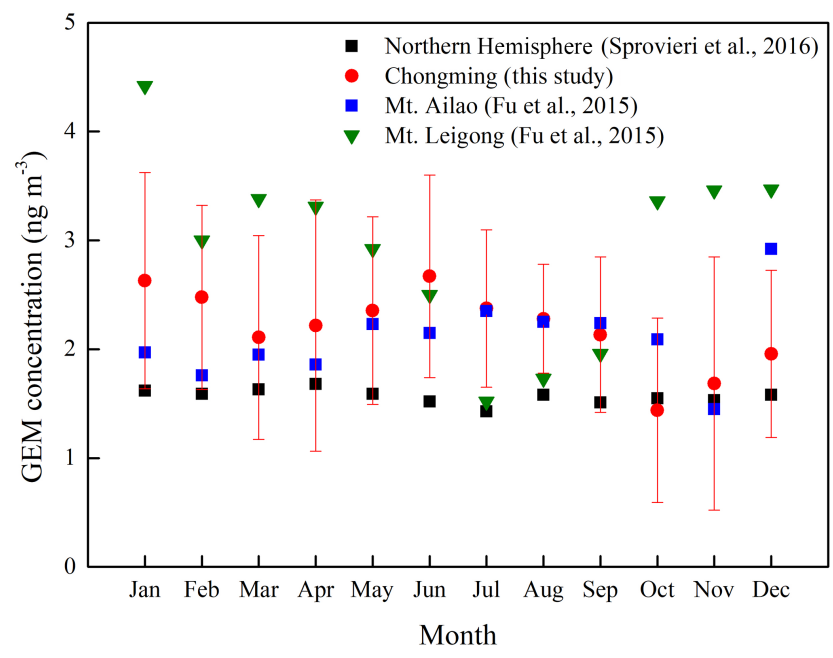

Figure 3. Monthly variations of GEM concentration at remote sites in China.

evaluate the impact of the missing data, we estimated the $\mathrm{Hg}$ concentrations in the missing months based on the data of the same months in 2015 and 2017 (Fig. S1). Combining the estimated data, we re-fitted the $\mathrm{Hg}$ concentrations, and the downward trend still remained robust and similar to the downward trend in the paper (Fig. S1). Thus, we assumed that the missing data were not very important and would not impact our main conclusions. 
Table 1. PCA component loading of GEM and other air pollutants.

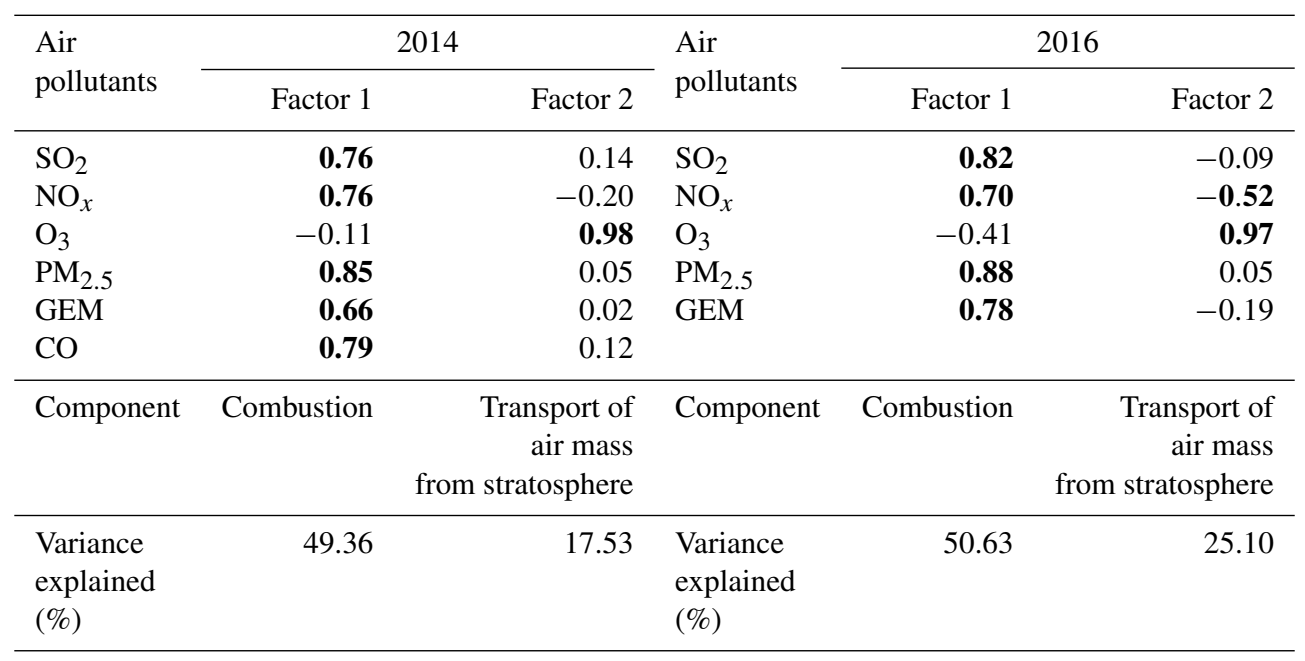

Note that values in bold were regarded as high loading (factor loading $>0.40$ or $<-0.40$ ).

Table S4 showed the $\mathrm{Hg}$ variation trends in different regions. A significant decrease of GEM concentrations in the Northern Hemisphere over the past 2 decades has been well documented (Weigelt et al., 2015; Cole et al., 2013; Kim et al., 2016). All the stations in Table S4 used Tekran instruments, except for the observations in South Korea. Different instruments could cause potential differences in the observation, but they were comparable and did not affect the conclusion of comparison of the downward trend (Slemr et al., 2015; Sprovieri et al., 2016). Weigelt et al. (2015) showed that GEM concentrations decreased from 1.75 in 1996 to $1.4 \mathrm{ng} \mathrm{m}^{-3}$ in 2009 at Mace Head, Ireland. The 10year trends of GEM concentrations at six ground-based sites in the Arctic and Canada also showed a decreasing trend at a rate of 13-35 $\mathrm{pg} \mathrm{m}^{-3} \mathrm{yr}^{-1}$ (Cole et al., 2013). In South Korea, the observed GEM concentration also showed a significant decrease in recent years (Kim et al., 2016). In South Africa, annual average GEM concentration at Cape Point decreased from 1.29 in 1996 to $1.19 \mathrm{ng} \mathrm{m}^{-3}$ in 2004 (Slemr et al., 2008) and increased from $0.93 \mathrm{ng} \mathrm{m}^{-3}$ in 2007 (Slemr et al., 2015) until 2016 (Martin et al, 2017). However, limited GEM monitoring sites and relative short -time spans in China restricted the view of long-term trends in atmospheric $\mathrm{Hg}$ concentration in this region. A preliminary assessment indicated that atmospheric $\mathrm{Hg}$ concentrations in China kept increasing before 2012 (Fu et al., 2015). The decreasing trend observed in our study was accordant with reported data at Mt. Changbai during 2014-2015 cited in the review of Fu et al. (2015). The atmospheric $\mathrm{Hg}$ at Chongming was influenced by and in turn reflected regional $\mathrm{Hg}$ emission and its cycle. Although the decline in atmospheric $\mathrm{Hg}$ was observed at many sites of the Northern Hemisphere, a much sharper decrease of $\mathrm{Hg}$ concentrations was observed at Chongming in our study. The specific reasons for the $\mathrm{Hg}$ concentration decrease in our study will be discussed in Sect. 3.4.

\subsection{Seasonal variation of GEM concentrations}

According to the decomposition result (Fig. 2c), we observed a strong seasonal cycle at Chongming. The GEM concentrations were highest in July and lowest in September, so GEM concentrations in the same month from different years were averaged to understand the detrended seasonal circle (Fig. 3). The error bars in the Fig. 3 represent the standard deviation of the monthly average. Observed GEM concentrations showed an obvious seasonal cycle. The mean GEM concentration in the warm season (from April to September) was $0.29 \mathrm{ng} \mathrm{m}^{-3}$ higher than that in the cold season. Such a seasonal variation trend was also observed at Nanjing, Miyun, Mt. Ailao, Mt. Waliguan, and Shangri-La (Zhang et al., 2013, 2016; Fu et al., 2015; Zhu et al., 2012). On the other hand, the GEM concentrations at Mt. Gongga, Mt. Daimei, Mt. Leigong, and Mt. Changbai in China were relatively higher in cold seasons. The average of atmospheric $\mathrm{Hg}$ concentrations in the Northern Hemisphere also had a trough value in summer (Sprovieri et al., 2016).

Seasonal variations of GEM concentration were generally attributed to the following factors, including natural and anthropogenic emissions, atmospheric chemical reactions, and air mass transport. The higher $\mathrm{Hg}$ concentrations in the cold season at Mt. Leigong were mainly explained by coal combustion for urban and residential heating during the cold season, whereas increasing solar radiation and soil/air temperature dominated the higher $\mathrm{Hg}$ concentrations at Mt. Ailao. In addition, sites in southern, eastern, and northeastern China were also impacted by anthropogenic emissions of GEM from the north and west by the northerly winter monsoon, while the sites located in western, southwestern, and northern 
Table 2. Emissions of the main air pollutants in the YRD region in 2014.

\begin{tabular}{lrrrr}
\hline \multirow{2}{*}{ Emission sectors } & \multicolumn{4}{c}{ Annual emissions } \\
\cline { 2 - 5 } & $\mathrm{SO}_{2}$ & $\mathrm{NO}_{x}$ & $\mathrm{PM}_{2.5}$ & GEM \\
$(\mathrm{kt})$ & $(\mathrm{kt})$ & $(\mathrm{kt})$ & $(\mathrm{t})$ \\
\hline Coal-fired power plants & 918.31 & 991.62 & 118.42 & 14.00 \\
Coal-fired industrial boilers & 311.03 & 271.94 & 79.91 & 9.80 \\
Residential coal combustion & 68.48 & 42.11 & 163.93 & 0.40 \\
Cement clinker production & 207.48 & 371.13 & 208.02 & 4.70 \\
Iron and steel production & 480.97 & 142.80 & 169.84 & 2.30 \\
Mobile oil combustion & 38.43 & 1786.74 & 98.00 & 1.90 \\
Other sectors & 348.83 & 316.28 & 382.48 & 2.50 \\
\hline
\end{tabular}

China were impacted in the warm season (Fu et al., 2015). As at most sites in the Northern Hemisphere, high wet $\mathrm{Hg}$ precipitation, probably induced by faster GEM oxidation, led to lower $\mathrm{Hg}$ concentrations in summer.

Source emission was a significant factor that affected GEM concentrations in the air. The GEM concentrations at a remote site were generally regarded under the impact of regional emissions. Therefore, the emissions in the YRD regions (Anhui, Zhejiang, Jiangsu, and Shanghai) were calculated during 2014-2016. However, the anthropogenic emissions were in the range of $2.5-2.7 \mathrm{t}$, which was almost unchanged. Compared to the anthropogenic emissions, we observed almost synchronized trends between natural emissions and air $\mathrm{Hg}$ concentrations in Fig. 4. The natural emissions showed a huge seasonal variation, from -5.4 to $8.4 \mathrm{t}$. The largest natural emissions were observed in summer when the highest GEM concentrations were monitored. In the autumn, the natural emissions performed as the largest deposition direction amount and the GEM concentrations were the lowest in the whole year. Therefore, natural emissions instead of anthropogenic emissions were supposed to be a significant factor that affected the seasonal cycle of GEM concentrations (Fig. 4). The seasonal trend of natural emissions was closely related with the canopy types in YRD areas, where widely subtropical forests, paddy fields, and dry farming were observed (Fig. S2). The high temperature will speed up decomposition of organic compound in soil, which leads to $\mathrm{Hg}$ emissions from farmland and forest in the YRD region in summer (Luo et al., 2016; Yu et al., 2018). In autumn and winter, with the decrease of temperature (Table S2), the role of soil changed from $\mathrm{Hg}$ source to sink, which reduced the $\mathrm{Hg}$ concentrations in the air (Wang et al., 2016). At the same time, the growing vegetation in autumn also absorbed air $\mathrm{Hg}$, resulting in lower $\mathrm{Hg}$ concentrations compared to those in winter. Transport also overall enhanced the observed seasonal variation of GEM concentrations at Chongming Island. According to the statistics of backward trajectories in Sect. 3.4, the GEM concentrations in the air mass which did not pass via the YRD regions also showed high GEM concentration in the warm season in 2014 (Fig. S3).

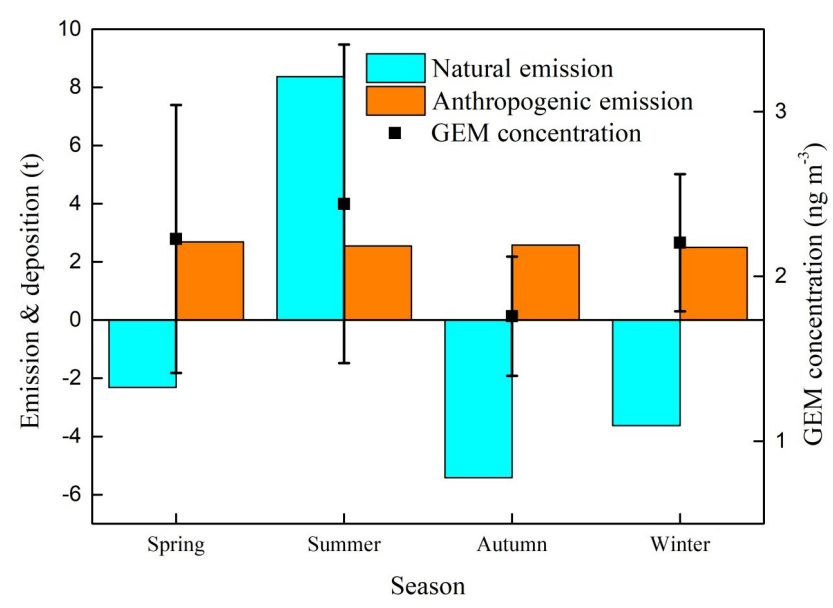

Figure 4. Seasonal cycle of GEM concentrations, anthropogenic emissions, and natural emissions during 2014-2016. The error bars represent the standard deviation of seasonal average. Negative values of natural emissions represent mercury deposition, and positive values of natural emissions represent natural emissions.

From Fig. 2, we also observed more pronounced seasonal variation in 2014, which could be attributed to the lower wet deposition and GEM oxidation. On the one hand, as a coastal site, the Chongming Island was abundant with $\cdot \mathrm{OH}$. The increase of $\mathrm{O}_{3}$ concentration from the summer of 2014 to 2016 may contribute to a higher oxidation of GEM in 2016. On the other hand, higher wet $\mathrm{Hg}$ deposition in summer was approximately 6.6 times that in the winter at Chongming (Zhang et al., 2010). Meanwhile, the rainfall in 2016 summer $(546 \mathrm{~mm})$ was higher than the rainfall in $2014(426 \mathrm{~mm})$. Therefore, the higher oxidation and wet deposition rate of $\mathrm{Hg}$ in the summer of 2016 would reduce the concentration difference between summer and winter, which led to a less pronounced seasonal variation in 2016. Meanwhile, the higher oxidation and wet deposition in 2016 also contributed to the downward trend of GEM by reducing the seasonality in spring and summer (Fig. S3).

\subsection{Source apportionment of atmospheric $\mathrm{Hg}$ pollution}

According to the PSCF result, the YRD region, including Shanghai, Jiangsu, Anhui, and Zhejiang provinces, was the dominant source region in both 2014 and 2016 (Fig. 5). Therefore, $\mathrm{Hg}$ emissions from these areas would contribute to high proportion of $\mathrm{Hg}$ pollution at Chongming Island. The offshore area mainly around Jiangsu province also had a high PSCF value because some trajectories from North China, especially Shandong province, transport to Chongming Island through this area. Compared to the result in 2014, the PSCF value showed an obvious decline in the East China Sea in 2016. The decline from the East China Sea may be caused by the downward trend of GEM concentrations in South Korea and Japan (Kim et al., 2013, 2016), where the anthro- 


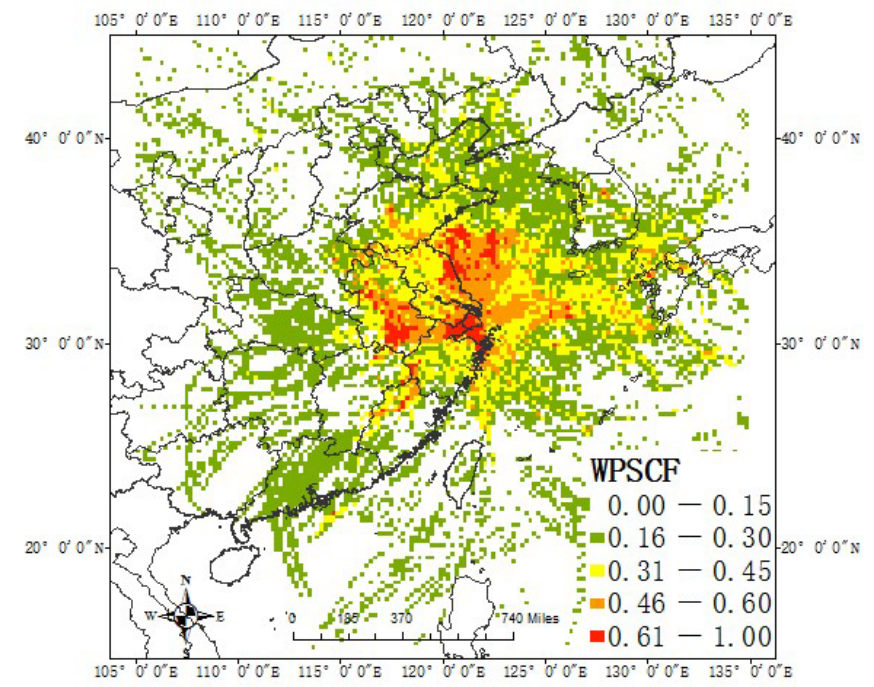

(a) 2014

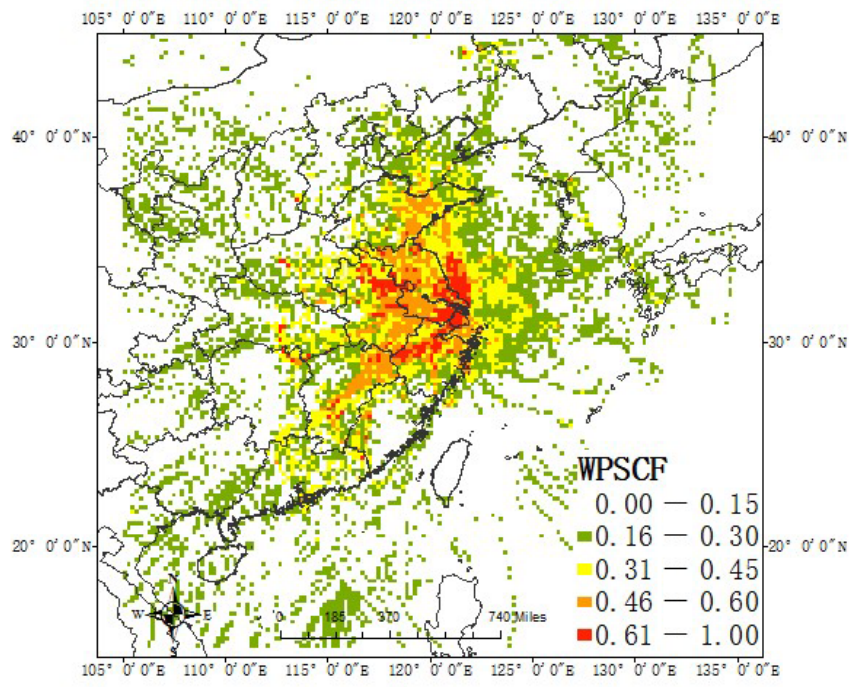

(b) 2016

Figure 5. Source regions of GEM at the monitoring site from the PSCF model in (a) 2014 and (b) 2016.

pogenic $\mathrm{Hg}$ emissions were reduced by 13 and $4 \%$ during 2010-2015, respectively (UNEP 2013, 2018). The air mass from Japan and South Korea would pass through the East China Sea to Chongming.

The PCA method was applied to preliminarily identify the potential source sectors. In the studied period, a total of two factors were identified in 2014 and 2016, respectively. The first factor had strong factor loadings of GEM, $\mathrm{SO}_{2}, \mathrm{NO}_{x}$, $\mathrm{CO}$, and $\mathrm{PM}_{2.5}$ in both 2014 and 2016 (no CO data in 2016 due to equipment problems). The first factor accounted for $49 \%$ variance in 2014 and $50 \%$ variance in 2016 (Table 1). The results indicated common significant source sectors of the above five air pollutants, which could also be proven from emission inventories (Table 2). The dominant source industries included coal-fired power plants, coal-fired industrial boilers, and cement clinker production. The PCA results showed that anthropogenic emissions were the main source of GEM during the sampling period.

The second factor in both 2014 and 2016 had a strong positive loading on $\mathrm{O}_{3}$ and negative loading on $\mathrm{NO}_{x}$. Considering the low loading of $\mathrm{CO}$ and high loading of $\mathrm{O}_{3}$, the second factor represented the transport of air mass from the stratosphere (Fishman and Seiler, 1983; Jaffe, 2010). The air mass from stratosphere would increase the $\mathrm{O}_{3}$ concentration. $\mathrm{O}_{3}$ reacted with NO, which was negatively correlated with NO. However, the low loading on GEM of the second factor indicated that it had no relationship with GEM concentrations at Chongming when looking at whole-year data.

\subsection{The influence of anthropogenic emissions}

To further understand the reason for the downward trend, we firstly compared the meteorological conditions in both 2014 and 2016. We noted that the difference of annual temperature, solar radiation, and relative humidity were constrained in the range of $17.13 \pm 7.48^{\circ}, 165.55 \pm 45.87 \mathrm{~W} \mathrm{~m}^{-2}$, and $75.38 \pm 5.82 \%$, respectively (Table S2). The coefficients of variation for annual mean of these meteorological conditions in 2014 and 2016 were 2.6, 6.7, and $0.2 \%$, respectively. In addition, the wind rose was similar, and the dominating wind was from the southeast in both 2014 and 2016 (Fig. S4). The HYSPLIT results also provided similar trajectories in 2014 and 2016 (Fig. 6). Therefore, we assumed that the meteorological condition was not the dominant reason for the GEM decline at Chongming site.

To further quantify the driver of the GEM decline, a trajectory-based analysis method was used in this study. The $72 \mathrm{~h}$ air mass back trajectories were calculated using HYSPLIT for every $8 \mathrm{~h}$, starting at the observation site. Approximately 918 and 832 trajectories were calculated in the sampling period in 2014 (1 March to 31 December 2014) and 2016 (26 March to 31 December 2016), respectively. The trajectories were grouped into three clusters in each year according to geographical regions (Fig. 6). The first cluster of trajectories mainly passed through the regions (e.g., North China) north and northwest of Chongming Island before arriving at our monitoring site, which is denoted as cluster NCP. The second cluster mainly passed the YRD region to Chongming, which is denoted as cluster SW-YRD. The third type mainly originated from the East China Sea, South Korea, Japan, and the northeastern Asia region, and then arrived at our monitoring sites directly without passing mainland China. This type of trajectory is denoted as cluster ABROAD. Some trajectories which originated from the East China Sea and crossed mainland China before arriving at Chongming were grouped into cluster NCP or SW-YRD 

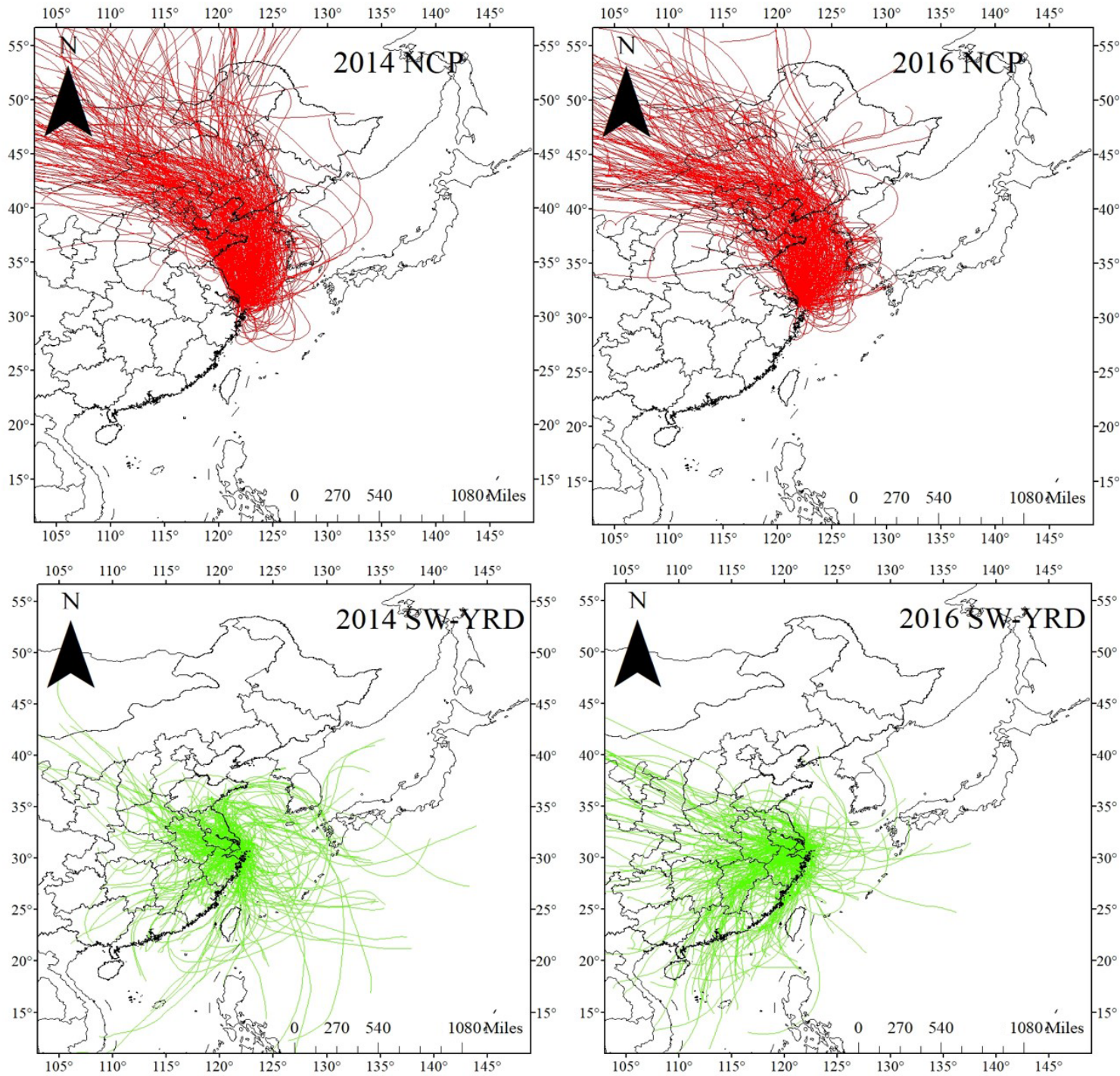

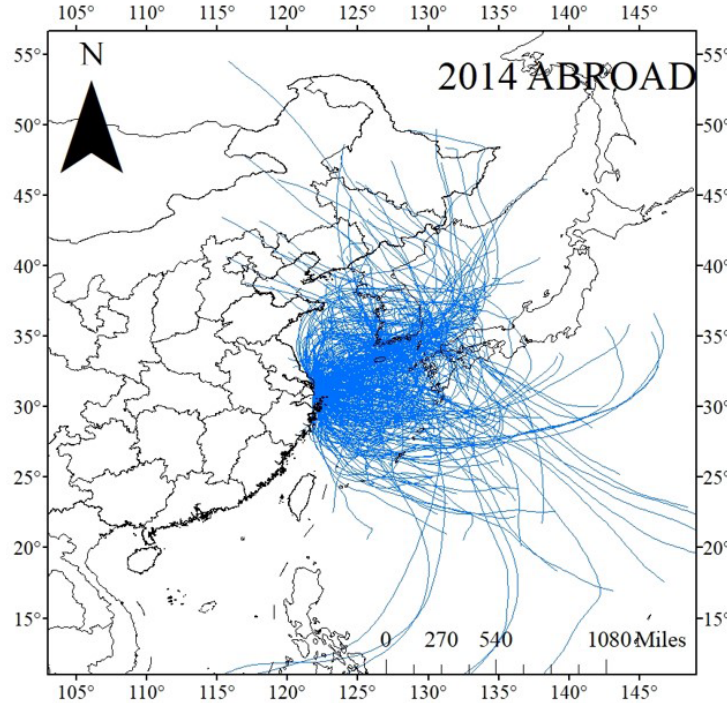

(a) 2014

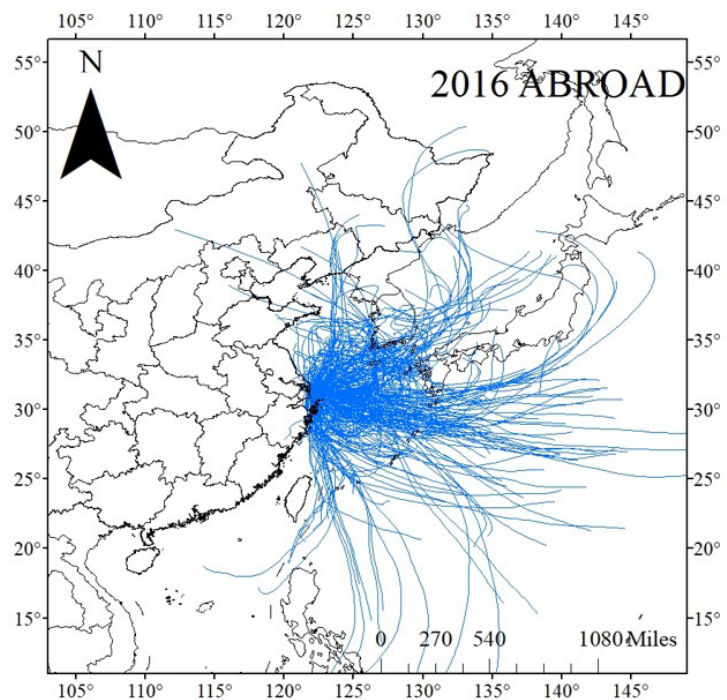

(b) 2016

Figure 6. The back trajectories map for cluster NCP, SW-YRD and ABROAD in (a) 2014 and (b) 2016. (NCP - North China Plain, SW-YRD - southwestern region and the Yangtze River Delta, and ABROAD - abroad). 
Table 3. The statistics of cluster and estimated contribution of GEM reduction in 2014 and 2016.

\begin{tabular}{|c|c|c|c|c|c|c|c|}
\hline \multirow[b]{2}{*}{ Time } & \multirow[b]{2}{*}{ Cluster } & \multicolumn{3}{|c|}{ Trajectories } & \multirow[b]{2}{*}{$\begin{array}{c}\text { GEM } \\
\text { concentration, } \\
C_{j}\left(\mathrm{ng} \mathrm{m}^{-3}\right)\end{array}$} & \multirow[b]{2}{*}{$\begin{array}{c}\text { Trajectory- } \\
\text { weighted concentration, } \\
\mathrm{TWC}_{j},\left(\mathrm{ng} \mathrm{m}^{-3}\right)\end{array}$} & \multirow[b]{2}{*}{$\begin{array}{l}\text { Contribution to } \\
\text { GEM reduction, } \\
\mathrm{CR}_{i}\end{array}$} \\
\hline & & Numbers & Ratio & $\begin{array}{l}\text { Average } \\
\text { Ratio } \\
\text { (AR) }\end{array}$ & & & \\
\hline \multirow{3}{*}{2014} & $\mathrm{NCP}$ & 285 & $33 \%$ & $32 \%$ & 2.33 & 0.79 & \\
\hline & SW-YRD & 304 & $35 \%$ & $37 \%$ & 3.19 & 1.18 & \\
\hline & ABROAD & 275 & $32 \%$ & $31 \%$ & 2.58 & 0.77 & \\
\hline \multirow{3}{*}{2016} & $\mathrm{NCP}$ & 237 & $31 \%$ & $32 \%$ & 1.48 & 0.50 & $26 \%$ \\
\hline & SW-YRD & 302 & $39 \%$ & $37 \%$ & 1.87 & 0.69 & $44 \%$ \\
\hline & ABROAD & 230 & $30 \%$ & $31 \%$ & 1.44 & 0.43 & $30 \%$ \\
\hline
\end{tabular}

depending on the regions they crossed. The trajectories for each of the three clusters in 2014 and 2016 are shown in Table 3 .

Table 3 shows the detail statistics data of the three classifications. From 2014 to 2016, the whole China region (NCP, SW-YRD) contributed to $70 \%$ of the GEM decline at Chongming Island. Considering the downward trend of the emission inventory and atmospheric pollutants from 2014 to 2016 in NCP and SW-YRD regions (Table S5, Table S6), the reason for the downward trend could be attributed to the effectiveness of existing air pollution control measures in China (SC, 2013; MEP, 2014). Meanwhile, cluster NCP, cluster SW-YRD, and cluster ABROAD caused 26, 44, and $30 \%$ of the GEM decline, respectively (Table 3). Cluster SWYRD contributed to $44 \%$ of reduction, suggesting that air pollution controls on anthropogenic emissions in YRD region dominated the recent decrease of GEM concentrations at the Chongming site. The largest decline of $\mathrm{Hg}$ concentration $\left(1.32 \mathrm{ng} \mathrm{m}^{-3}\right)$ was also observed in the cluster SWYRD, which demonstrated the efficiency of emission reduction in YRD region (Table S5, Table S6). Moreover, the ABROAD region caused $30 \%$ of GEM decline from 2014 to 2016, which implied a global effort in atmospheric Hg emission control under the guidance of the Minamata Convention on Mercury.

\section{Conclusions}

Atmospheric $\mathrm{Hg}$ was continuously measured for 3 years at a regional background site in the YRD region. During the sampling period, a downward trend for GEM concentrations $\left(-0.60 \pm 0.08 \mathrm{ng} \mathrm{m}^{-3} \mathrm{yr}^{-1}\right)$ at Chongming Island was observed. The seasonal GEM cycle was dominated by the natural emissions, while the annual GEM concentration trend was mainly impacted by anthropogenic emissions. By using a new approach that considers both cluster frequency and the $\mathrm{Hg}$ concentration associated with each cluster, we calculated that atmospheric $\mathrm{Hg}$ from the NCP region, SW-YRD region, and $A B R O A D$ region caused 26, 44, and $30 \%$ of the decline of GEM concentrations at the Chongming monitoring site during 2014-2016, respectively. The results suggested that reduction of anthropogenic emissions in mainland China was the main cause of the recent decreasing trend of GEM concentration at the Chongming site. The air pollution control policies in China, especially pollution control in the coal-fired power plants, coal-fired industrial boilers, and cement clinker production in the YRD region and Shandong province, significantly co-benefitted atmospheric $\mathrm{Hg}$ emission reduction. On the other hand, emission reduction from the ABROAD region, where clusters arrived at the Chongming monitoring site directly without passing mainland China, implied a global effort in atmospheric Hg emission control under the guidance of the Minamata Convention on Mercury. Considering that the Minamata Convention on Mercury came into force in 2017, continuous long-term observations of atmospheric $\mathrm{Hg}$ in China will be required for the assessment of policy effectiveness.

Data availability. All data are available from the authors upon request.

Supplement. The supplement related to this article is available online at: https://doi.org/10.5194/acp-18-8279-2018-supplement.

Competing interests. The authors declare that they have no conflict of interest.

Acknowledgements. This work is sponsored by the Natural Science Foundation of China (no. 21607090), Major State Basic Research Development Program of China (973 Program) (no. 2013CB430000), and the National Key R\&D Program of China (no. 2016YFC0201900)

Edited by: Ralf Ebinghaus

Reviewed by: two anonymous referees 


\section{References}

Arctic Monitoring and Assessment Programme and United Nations Environment Programme (AMAP/UNEP): Global Hg assessment 2013: sources, emissions, releases and environmental transport, AMAP/UNEP, Geneva, Switzerland, 2013.

Arctic Monitoring and Assessment Programme and United Nations Environment Programme (AMAP/UNEP): Global mercury assessment 2018 - draft technical background document, AMAP/UNEP, Geneva, Switzerland, 2018.

Chen, L., Zhang, W., Zhang, Y., Tong, Y., Liu, M., Wang, H., Xie, H., and Wang, X.: Historical and future trends in global sourcereceptor relationships of mercury, Sci. Total Environ., 610-611, 24-31, 2018.

Cole, A. S., Steffen, A., Pfaffhuber, K. A., Berg, T., Pilote, M., Poissant, L., Tordon, R., and Hung, H.: Ten-year trends of atmospheric mercury in the high Arctic compared to Canadian subArctic and mid-latitude sites, Atmos. Chem. Phys., 13, 15351545, https://doi.org/10.5194/acp-13-1535-2013, 2013.

Draxler, R. R.: Trajectory Optimization for Balloon Flight Planning, Int. J. Numer. Meth. Fl., 5, 13-23, 1996.

Draxler, R. R. and Hess, G. D.: An overview of the hysplit-4 modeling system for trajectories, Aust. Meteorol. Mag., 47, 295-308, 1998.

Fishman, J. and Seiler, W.: Correlative Nature of Ozone and Carbon Monoxide in the Troposphere: Implications for the Tropospheric Ozone Budget, J. Geophys. Res., 88, 3662-3670, 1983.

Fu, X. W., Feng, X. B, Zhu, W. Z., Wang, S. F., and Lu, J. L.: Total gaseous mercury concentrations in ambient air in the eastern slope of Mt. Gongga, South-Eastern fringe of the Tibetan plateau, China, Atmos. Environ., 42, 970-979, 2008a.

Fu, X. W., Feng, X. B., Zhu, W. Z., Zheng, W., Wang, S. F., and Lu, J. Y.: Total particulate and reactive gaseous mercury in ambient air on the eastern slope of the Mt. Gongga area, China, Appl. Geochem., 23, 408-418, 2008b.

Fu, X. W., Feng, X. B., Wang, S., Rothenberg, S., Shang, L., Li, Z., and Qiu, G.: Temporal and spatial distributions of total gaseous mercury concentrations in ambient air in a mountainous area in southwestern China: implications for industrial and domestic mercury emissions in remote areas in China, Sci. Total Environ., 407, 2306-2314, 2009.

Fu, X. W., Feng, X. B., Qiu, G. L., Shang, L. H., and Zhang, H.: Speciated atmospheric mercury and its potential source in Guiyang, China, Atmos. Environ., 45, 4205-4212, 2011.

Fu, X. W., Zhang, H., Yu, B., Wang, X., Lin, C.-J., and Feng, X. B.: Observations of atmospheric mercury in China: a critical review, Atmos. Chem. Phys., 15, 9455-9476, https://doi.org/10.5194/acp-15-9455-2015, 2015.

Hong, Q., Xie, Z., Liu, C., Wang, F., Xie, P., Kang, H., Xu, J., Wang, J., Wu, F., He, P., Mou, F., Fan, S., Dong, Y., Zhan, H., Yu, X., Chi, X., and Liu, J.: Speciated atmospheric mercury on haze and non-haze days in an inland city in China, Atmos. Chem. Phys., 16, 13807-13821, https://doi.org/10.5194/acp-16-138072016, 2016.

Hui, M. L., Wu, Q. R., Wang, S. X., Liang, S., Zhang, L., Wang, F. Y., Lenzen, M., Wang, Y. F., Xu, L. X., Lin, Z. T., Yang, H., Lin, Y., Larssen, T., Xu, M., and Hao, J. M.: Mercury flows in China and global drivers, Environ. Sci. Technol., 51, 222-231, 2017.

Jaffe, D.: Relationship betwen surface and free tropospheric ozone in the western U.S., Environ. Sci. Technol., 45, 432-438, 2010.
Kim, K.-H., Yoon, H.-O., Brown, R. J. C., Jeon, E.-C., Sohn, J.R., Jung, K., Park, C.-G., and Kim, I.-S.: Simultaneous monitoring of total gaseous mercury at four urban monitoring stations in Seoul, Korea, Atmos. Res., 132-133, 199-208, 2013.

Kim, K. H., Brown, R. J. C., Kwon, E., Kim, I. S., and Sohn, J. R.: Atmospheric mercury at an urban station in Korea across three decades, Atmos. Environ., 131, 124-132, 2016.

Landis, M. S., Stevens, R. K., Schaedlich, F., and Prestbo, E. M.: Development and characterization of an annular denuder methodology for the measurement of divalent inorganic reactive gaseous mercury in ambient air, Environ. Sci. Technol., 36, 3000-3009, 2002.

Li, S., Gao, W., Wang, S. X., Zhang, L., Li, Z. J., Wang, L., and Hao, J. M.: Characteristics of Speciated Atmospheric Mercury in Chongming Island, Shanghai, Environ. Sci., 37, 3290-3299, 2016.

Lin, C. J., Pongprueksa, P., Lindberg, S. E., Pehkonen, S. O., Byun, D., and Jang, C.: Scientific uncertainties in atmospheric mercury models I: Model science evaluation, Atmos. Environ., 40, 29112928, 2006.

Lindberg, S., Bullock, R., Ebinghaus, R., Engstrom, D., Feng, X. B., Fitzgerald, W., Pirrone, N., Prestbo, E., and Seigneur, C.: A synthesis of progress and uncertainties in attributing the sources of mercury in deposition, Ambio, 36, 19-33, 2007.

Luo, Y., Duan, L., Driscoll, C. T., Xu, G., Shao, M., Taylor, M., Wang, S. X, and Hao, J. M.: Foliage/atmosphere exchange of mercury in a subtropical coniferous forest in south China, J. Geophys. Res.-Biogeo., 121, 2006-2016, 2016.

Martin, L. G., Labuschagne, C., Brunke, E.-G., Weigelt, A., Ebinghaus, R., and Slemr, F.: Trend of atmospheric mercury concentrations at Cape Point for 1995-2004 and since 2007, Atmos. Chem. Phys., 17, 2393-2399, https://doi.org/10.5194/acp17-2393-2017, 2017

Mason, R. P., Reinfelder, J. R., and Morel, F. M. M.: Bioaccumulation of mercury and methylmercury, Springer, Netherlands, 1995.

Ministry of Environmental Protection (MEP) and State Administration for Quality Supervision and Inspection and Quarantine (AQSIQ): Emission standard of air pollutants for boilers, MEP, Beijing, China, 2014.

Pacyna, J. M., Travnikov, O., De Simone, F., Hedgecock, I. M., Sundseth, K., Pacyna, E. G., Steenhuisen, F., Pirrone, N., Munthe, J., and Kindbom, K.: Current and future levels of mercury atmospheric pollution on a global scale, Atmos. Chem. Phys., 16, 12495-12511, https://doi.org/10.5194/acp-16-124952016, 2016.

Pirrone, N., Keeler, G. J., and Nriagu, J. O.: Regional differences in worldwide emissions of mercury to the atmosphere, Atmos. Environ., 30, 2981-2987, 1996.

Polissar, A. V., Hopke, P. K., Paatero, P., Kaufmann, Y. J., Hall, D. K., Bodhaine, B. A., Dutton, E. G., and Harris, J. M.: The aerosol at Barrow, Alaska: long-term trends and source locations, Atmos. Environ., 33, 2441-2458, 1999.

Schroeder, W. H. and Munthe, J.: Atmospheric mercury - An overview, Atmos. Environ., 32, 809-822, 1998.

Slemr, F., Brunke, E. G., Labuschagne, C., and Ebinghaus, R.: Total gaseous mercury concentrations at the Cape Point GAW station and their seasonality, Geophys. Res. Lett., 35, 213-226, 2008. 
Slemr, F., Angot, H., Dommergue, A., Magand, O., Barret, M., Weigelt, A., Ebinghaus, R., Brunke, E.-G., Pfaffhuber, K. A., Edwards, G., Howard, D., Powell, J., Keywood, M., and Wang, F.: Comparison of mercury concentrations measured at several sites in the Southern Hemisphere, Atmos. Chem. Phys., 15, 31253133, https://doi.org/10.5194/acp-15-3125-2015, 2015.

Sprovieri, F., Pirrone, N., Ebinghaus, R., Kock, H., and Dommergue, A.: A review of worldwide atmospheric mercury measurements, Atmos. Chem. Phys., 10, 8245-8265, https://doi.org/10.5194/acp-10-8245-2010, 2010.

Sprovieri, F., Pirrone, N., Bencardino, M., D'Amore, F., Carbone, F., Cinnirella, S., Mannarino, V., Landis, M., Ebinghaus, R., Weigelt, A., Brunke, E.-G., Labuschagne, C., Martin, L., Munthe, J., Wängberg, I., Artaxo, P., Morais, F., Barbosa, H. D. M. J., Brito, J., Cairns, W., Barbante, C., Diéguez, M. D. C., Garcia, P. E., Dommergue, A., Angot, H., Magand, O., Skov, H., Horvat, M., Kotnik, J., Read, K. A., Neves, L. M., Gawlik, B. M., Sena, F., Mashyanov, N., Obolkin, V., Wip, D., Feng, X. B., Zhang, H., Fu, X., Ramachandran, R., Cossa, D., Knoery, J., Marusczak, N., Nerentorp, M., and Norstrom, C.: Atmospheric mercury concentrations observed at groundbased monitoring sites globally distributed in the framework of the GMOS network, Atmos. Chem. Phys., 16, 11915-11935, https://doi.org/10.5194/acp-16-11915-2016, 2016.

Sprovieri, F., Pirrone, N., Bencardino, M., D’Amore, F., Angot, H., Barbante, C., Brunke, E.-G., Arcega-Cabrera, F., Cairns, W., Comero, S., Diéguez, M. D. C., Dommergue, A., Ebinghaus, R., Feng, X. B., Fu, X., Garcia, P. E., Gawlik, B. M., Hageström, U., Hansson, K., Horvat, M., Kotnik, J., Labuschagne, C., Magand, O., Martin, L., Mashyanov, N., Mkololo, T., Munthe, J., Obolkin, V., Ramirez Islas, M., Sena, F., Somerset, V., Spandow, P., Vardè, M., Walters, C., Wängberg, I., Weigelt, A., Yang, X., and Zhang, H.: Five-year records of mercury wet deposition flux at GMOS sites in the Northern and Southern hemispheres, Atmos. Chem. Phys., 17, 2689-2708, https://doi.org/10.5194/acp17-2689-2017, 2017.

State Council of the People's Republic of China (SC): Action plan of national air pollution prevention and control, SC, Beijing, China, 2013.

Steffen, A., Scherz, T., Olson, M., Gay, D., and Blanchard, P.: A comparison of data quality control protocols for atmospheric mercury speciation measurements, J. Environ. Monit., 14, 752765, 2012

Streets, D. G., Devane, M. K., Lu, Z., Bond, T. C., Sunderland, E. M., and Jacob, D. J.: All-Time releases of mercury to the atmosphere from human activities, Environ. Sci. Technol., 45, 1048510491, 2011.

Sung, J.-H., Roy, D., Oh, J.-S., Back, S.-K., Jang, H.-N., Kim, S.H., Seo, Y.-C., Kim, J.-H., Lee, C. B., and Han, Y.-J.: Transboundary movement of mercury in the Northeast Asian region predicted by CAMQ-Hg from anthropogenic emissions distribution, Atmos. Res., 203, 197-206, 2018.

Wang, X., Lin, C.-J., Yuan, W., Sommar, J., Zhu, W., and Feng, X.: Emission-dominated gas exchange of elemental mercury vapor over natural surfaces in China, Atmos. Chem. Phys., 16, 1112511143, https://doi.org/10.5194/acp-16-11125-2016, 2016.

Wang, Y. Q., Zhang, X. Y., and Draxler, R. R.: TrajStat: GIS-based software that uses various trajectory statistical analysis methods to identify potential sources from long-term air pollution mea- surement data, Elsevier Science Publishers B. V., New York, 938-939, 2009.

Weigelt, A., Ebinghaus, R., Manning, A. J., Derwent, R. G., Simmonds, P. G., Spain, T. G., Jennings, S. G., and Slemr, F.: Analysis and interpretation of 18 years of mercury observations since 1996 at Mace Head, Ireland, Atmos. Environ., 100, 85-93, 2015.

Wu, Q., Wang, S., Li, G., Liang, S., Lin, C. J., Wang, Y., Cai, S., Liu, K., and Hao, J.: Temporal trend and spatial distribution of speciated atmospheric mercury emissions in China during 19782014, Environ. Sci. Technol., 50, 13428-13435, 2016.

$\mathrm{Xu}, \mathrm{X}$. and Akhtar, U. S.: Identification of potential regional sources of atmospheric total gaseous mercury in Windsor, Ontario, Canada using hybrid receptor modeling, Atmos. Chem. Phys., 10, 7073-7083, https://doi.org/10.5194/acp-107073-2010, 2010.

Yu, Q., Luo, Y., Wang, S., Wang, Z., Hao, J., and Duan, L.: Gaseous elemental mercury (GEM) fluxes over canopy of two typical subtropical forests in south China, Atmos. Chem. Phys., 18, 495509, https://doi.org/10.5194/acp-18-495-2018, 2018.

Zhang, G. Y., Zhou, L. M., Zheng, X. M., and Huang, W. D.: Temporal distribution and potential hazards of wet depostion mercury in Yangtze River Estuary, Urban Environmental \& Urban Ecology, 1-4, 2010.

Zhang, H., Fu, X. W., Lin, C.-J., Wang, X., and Feng, X. B.: Observation and analysis of speciated atmospheric mercury in ShangriLa, Tibetan Plateau, China, Atmos. Chem. Phys., 15, 653-665, https://doi.org/10.5194/acp-15-653-2015, 2015.

Zhang, H., Fu, X., Lin, C.-J., Shang, L., Zhang, Y., Feng, X., and Lin, C.: Monsoon-facilitated characteristics and transport of atmospheric mercury at a high-altitude background site in southwestern China, Atmos. Chem. Phys., 16, 13131-13148, https://doi.org/10.5194/acp-16-13131-2016, 2016.

Zhang, L., Wang, S. X., Wang, L., and Hao, J. M.: Atmospheric mercury concentration and chemical speciation at a rural site in Beijing, China: implications of mercury emission sources, Atmos. Chem. Phys., 13, 10505-10516, https://doi.org/10.5194/acp-13-10505-2013, 2013.

Zhang, L., Wang, S. X., Wang, L., Wu, Y., Duan, L., Wu, Q. R., Wang, F. Y., Yang, M., Yang, H., Hao, J. M., and Liu, X.: Updated emission inventories for speciated atmospheric mercury from anthropogenic sources in China, Environ. Sci. Technol., 49, 3185-3194, 2015.

Zhang, L. M., Wright, L. P., and Blanchard, P.: A review of current knowledge concerning dry deposition of atmospheric mercury, Atmos. Environ., 43, 5853-5864, 2009.

Zhang, Y. X., Jacob, D. J., Horowitz, H. M., Chen, L., Amos, H. M., Krabbenhoft, D. P., Slemr, F., St Louis, V. L., and Sunderland, E. M.: Observed decrease in atmospheric mercury explained by global decline in anthropogenic emissions, Proc. Nat. Acad. Sci. USA, 113, 526-231, 2016.

Zhao, B., Wang, S. X., Liu, H., Xu, J. Y., Fu, K., Klimont, Z., Hao, J. M., He, K. B., Cofala, J., and Amann, M.: NO${ }_{x}$ emissions in China: historical trends and future perspectives, Atmos. Chem. Phys., 13, 9869-9897, https://doi.org/10.5194/acp13-9869-2013, 2013. 
Zhu, J., Wang, T., Talbot, R., Mao, H., Hall, C. B., Yang, X., Fu, C., Zhuang, B., Li, S., Han, Y., and Huang, X.: Characteristics of atmospheric Total Gaseous Mercury (TGM) observed in urban Nanjing, China, Atmos. Chem. Phys., 12, 12103-12118, https://doi.org/10.5194/acp-12-12103-2012, 2012. 